\title{
Female Teachers' Perception of Reflective Teaching as a Teacher Development Tool in the Saudi Context
}

\author{
Nadia Shukri \\ English Language Institute \\ King Abdul Aziz University \\ P.O. Box 42890, Jeddah, KSA, 21551. \\ E-mail: ndshukri@gmail.com
}

Doi:10.7575/aiac.alls.v.5n.5p.192

URL: http://dx.doi.org/10.7575/aiac.alls.v.5n.5p.192
Received: 23/07/2014

Accepted: 09/08/2014

\begin{abstract}
Teacher development in the EFL context has been well-established in Western educational institutions. However, although there are some limited studies in the Middle East, it is still under-researched in Saudi Arabia. This study investigates the EFL teachers' perceptions of reflective teaching as a tool for teacher development and its challenges in higher education in Saudi Arabia. It also aims to raise teachers' awareness of the importance of teacher development and its empowering impact in meeting their students' needs. Based on a review of previous studies, the present study hypothesized a significant relevance between reflective teaching practice and the promotion of professional development. A structured questionnaire is used as a quantitative methodology followed by qualitative analysis of the findings. The findings support the hypothesis in which the participants' views revealed a strong relationship between reflective teaching and professionalism in teaching. Finally, further recommendations that suggest methods of reflective teaching are proposed.
\end{abstract}

Keywords: Teacher development, training, and professional development, higher education.

\section{Introduction}

EFL teachers are in an endless struggle to meet the needs of the curriculum and achieve students' needs for their future career. Therefore, in an attempt to fulfill such a mission, EFL teachers have to be responsible and knowledge-grounded of the updated learning theories and approaches.

In this regard, teachers need to apply different approaches, evaluate and reflect upon their teaching practices in order to become competent and professional teachers. Hence, teachers' competence involves a balance between enhancing the students' learning and accomplishing their careers and research studies in an attempt to align with the updated world and gain sufficient training in the EFL field. To this point, referring to the Saudi context, the English Language Institute provides a comfortable enriching environment to motivate and help teachers to achieve such a balance and attain ultimate professionalism.

\subsection{Saudi Context:}

The English Language Institute is situated in Jeddah, King Abdul Aziz University. In order to abide the CEA (Commission on English Language Accreditation) accreditation standards, teacher performance and the quality of teaching are major priorities to be considered to meet the needs of foundation year students. The Professional development Unit is an active unit where it aims to improve the quality performance of its teachers by providing in house training for the teachers.

The English Language institute works in collaboration with the Oxford University press to provide training for the teachers such as finding strategies to motivate students, integrating technology with teaching and integrating the four skills in the classroom. Other committees under the unit are the teacher evaluation committee where teachers are observed regularly to enhance quality performance. Also, recently a mentoring program has been designed for novice/experienced teachers for the purpose of supporting and providing guidance.

An influx of Saudi and foreign teachers from different cultures and backgrounds are faculty members. They all cater to all foundation year students at a yearly basis. BA, MA, Phd holders' degrees in English, Literature, Applied Linguistics, TESOL, and CELTA certificates. They have at least 3 years of teaching experience in the EFL field. There is a continuous In-house training, Oxford University press faculty training, and initiated development groups to establish a learning community among teachers. Recently, a peer observation group has been formed for the purpose of development, change, collegiality, growth and ongoing support among peers in the institution.

\subsection{Statement of the Problem}

Teacher Development is still a new area to be researched in the Saudi context. The study aims to investigate teachers' perceptions towards teacher development and reflective teaching. With the advent of technology and the diverse 
methods and demands of teaching, teachers face numerous challenges, they may be aware of the training performance but may lack to reflect upon themselves and seek ways to enhance their teaching practices, which is in turn represented in the reflective teaching. To support this, Hazmi (2003), in the Saudi context, teachers may need to play an active role in EFL teacher training in pre-service and inservice training, so that they contribute to their country. In order to be effective teachers, teachers may need to reflect upon their profession to discover ways of improving it and meet the challenges of the future with updated knowledge and recent pedagogical practices. Accordingly, the focus of this paper is to investigate teachers' awareness of teacher development activities and reflective practices.

\section{Literature Review}

\subsection{Perceptions towards teacher development}

Examining the perceptions and beliefs towards teacher development and reflective teaching may assist in developing an awareness of the current situation in the English Language Institute within the Saudi context. As referred by Borg (2006), an awareness of teachers' perceptions as professionals in an academic setting will contribute to the need of teacher training in enhancing the educational system. Borg (2003) describes teacher's beliefs and perceptions as constituents of a wider notion of teacher cognition. The relevance of teachers' perspectives comes under teacher cognition and it includes experiences in schooling, professional lives and classroom practices (Borg, 2003). Educational research in the last 25 years has recognized the effect of teacher cognition on teachers' professional lives (Richardson, 1996). As claimed by Borg (2003), it is now accepted that teachers are active, thinking decision-makers who make instructional decisions by considering complex, and context-sensitive networks of knowledge, thoughts, and beliefs. Thus, teachers' perceptions hold a significant role in the arena of teacher education.

Al-Shihy (2003) investigated 120 Omani EFL teachers' perceptions of the EFL teacher education program at Sultan Qabous University (SQU). She examined four aspects of the program: the academic training; the pedagogical training; its organization; and the teaching and evaluation techniques applied by the university professors. The first aim was to conduct a large quantitative survey to assist in understanding the perceptions of ELT student teachers becoming reflective practitioners. The Omani general education and higher education systems share many characteristics with the systems in the neighboring Gulf Cooperation Council countries namely Bahrain, Kuwait, Qatar, Saudi Arabia, the United Arab Emirates and Yemen. This study, therefore, has its implications for training ELT student teachers in these contexts. The second aim was to make an original contribution to knowledge about the role of the ELT teacher trainers in the Omani context. There has been some debate in the literature about this aspect of ELT teacher education, but most has been concerned with discussing theories, approaches and strategies associated with reflection in general. It has been recommended that technology meditated learning, observation tasks and activities, learning tasks and activities, and peer collaboration to be implemented among student teachers.

Al-Issa (2005) found that the teachers agreed on the usefulness of the pedagogical courses and the specialization courses taken by the trainees, while the general education and university elective courses were of secondary necessity. The teachers rated the teaching practicum from being unsatisfactory to somewhat satisfactory. However, as mentioned by Al-Issa (2005) no research so far has investigated the effect of trainers in the teaching developmental process on improving novice teachers' competence. To this point, Al-Issa (2005) thinks that teacher trainers are effective sociable agents who can positively influence their student teachers' thinking and performance. However, he further notes that the trainers might fail to prepare the student teachers to make decisions and reflect critically on their practices in Oman which produced unsatisfactory feedback.

In her study, An exploration of EFL Teacher's conceptions of Reflective Practice in the UAE (United Arab Emirates), six Arab teachers participated (Constantinou, 2009). The data was collected from teacher interviews, reflection journals, and classroom observations. The findings revealed that teachers have a general understanding of reflective practice activities, and by engaging them in reflective practice activities, it has motivated teachers to question their theories and conceptions of teaching. Finally, the study provided evidence that reflective practice is a major factor in teacher development. So far there has been no study specifically done in this area in the Saudi context.

\subsection{Teacher Development and Teacher Training}

Teacher development (henceforth TD) is a growing field in the EFL field in the Arab context. TD refers to the ongoing professional growth of teachers which may take the form of formal in-service training, such as attendance of short or long courses or at professional conferences (Thornbury, 2006). Thornbury adds that TD is more typically associated with:

informal, collegial, and classroom-based programs that incorporate cycles of classroom practice and reflection which include activities as: A mentoring system, where more experienced teachers work alongside novicee teachers, including taking part in team teaching; classroom observation, by peers, mentors or supervisors, plus feedback, Keeping a teaching journal, action research, attending locally based workshops and seminars and guided reading and discussion (225).

Thus, TD, and teacher training (TT), come within the larger orbit of teacher education (Thornbury, 2006), both concepts share similarities and differences. One the one hand, TD has a 'whole person' orientation aimed at developing the teacher's capacity for self-directed growth and professional well-being. On the other hand, TT is oriented toward developing technical goals, such as improving classroom skills and subject knowledge. 
Underhill (1988) explains that TT is associated with pedagogic skills, topic knowledge, methodology, and the employment of techniques and materials; while TD concerns teacher effectiveness in the classroom, confidence of self performance, attitude towards learners and learning, and role of teachers' influence concerning the welfare of students. TD is considered to be the teacher's resource for inner change. It is 'centered on personal awareness of the possibilities for change...It is a self-reflective process... where it also draws on the teacher's own inner resource for change' (Head and Taylor, 1997, p. 1). Moreover, Freeman (1982) asserts that TT addresses the enhancing teaching skills such as lesson planning or teacher conversation while developing an emphasis on the process of teacher reflection to change teaching practice which can lead to both personal and professional development. Also, he adds that TD is a constantly evolving process of growth and change in teaching. TT and TD share common aspects in which both are employed to improve teaching practices so that one can perform in the best interest of the student. Woodward (1999), on the other hand highlighted some differences between teacher training and teacher development which are displayed in the following table 1

Table 1. The characteristics of TT and TD by Woodward (1999, p. 9)

\begin{tabular}{ll}
\hline Teacher Training & Teacher Development \\
\hline Compulsory & Voluntary \\
Competency based & Holistic \\
Short term & Long term \\
One-off & Ongoing \\
Temporary & Continual \\
External agenda & Internal agenda \\
Skill/technique and knowledge & Awareness based, angled towards personal \\
based & growth and the development of \\
& attitudes/insights. \\
Compulsory for entry to the & Non-compulsory \\
profession & \\
Top-down & Bottom-up \\
Product/certificate weighted & Process-weighted \\
Means you can get a job & Means you can stay interested in your job \\
Done with experts & Done with peers \\
\hline
\end{tabular}

\subsection{Reflective Teaching}

Reflective teaching practice is widely accepted and applied by teachers worldwide. As noted by Dewey (1933) in reflective teaching, teachers and students collect data about teaching, examine their attitudes, beliefs, and teaching practices, and use that information as a basis for critical reflection. Dewey (1933) focuses on the attitudes of openmindedness, responsibility and wholeheartedness of the reflective teacher, which he argues is integral to reflective action. In the same way, Freeman (1989) emphasizes that the reflective teacher should give attention to: attitude, awareness, skills and subject knowledge as a decision making model. The concept of reflective action involves:

a willingness to engage in self-appraisal and development. It implies flexibility, rigorous analysis with objectives, It is a cyclical process in which teachers monitor, evaluate and revise their own practice... Reflective teaching requires competence in methods of evidence-based classroom enquiry, to support the progressive development of higher standards of teaching (Pollard, 2005, p. 13).

For further explanation, Schon (1987) contends that a carefully planned classroom session has to be constantly monitored by the teacher as it progresses. He notes that an in-progress awareness of the classroom session allows a teacher to accommodate for changes as situations demand. The post-action of reflecting, analyzing and evaluating, planning and preparation; which leads to a cycle of continued improvement. In this regard, Stenhouse (1975) claims that in order to reach ultimate professionalism, it is necessary to engage in autonomous self-development through systematic self-study. This is where reflective practice comes into the picture as Stenhouse $(1975$, p.144) further notes that reflective practice involves 'commitment to: 1) critical/systematic reflection; 2) questioning their practice for TD; 3) self-study; 4) teaching observation; and 5) intellectual curiosity to question and test theory in practice.' Not only reflective practice enhances teacher learning but extensive knowledge is gained (Harmer, 2007). This could take place through cooperative, collaborative venture and peer tutoring (Harmer, 2007).

Pertaining the Arab context, Al-Issa and Al-Bulushi (2010) pose that the reflective teaching practice has become a central theme in professional growth at the pre-service teacher education level almost everywhere. The quantitative part of their study describes the responses of 90 final year ELT student teachers and eight of their trainers at Sultan Qaboos University in the Sultanate of Oman. It is a survey about the roles, strategies used to assist the student teachers to reflect on their teaching. The results show that while the trainers have helped their student teachers to develop as reflective teachers, there are certain issues adopted by the trainers that need to be reconsidered, as they can have negative implications for teacher preparation. Issa and Al-Bulushi (2010) concluded that teachers are required to be dynamic agents of change, with the potential to make informed decisions and reflect critically on the context and find solutions to such problems to help produce competent English users who can contribute to the welfare of Oman. 
In the views of the following critics, reflective practice assists in enhancing education and student learning. Bartlett (1990) emphasizes that becoming a reflective teacher involves moving beyond the basic level with questioning and eventually be a part of a expanded educational objective. Desimons (2009) suggests that we apply recent research knowledge to improve our comprehension of measures and methodology for studying the effects of teachers' professional development on teaching and on student learning. She also suggests the importance of maximizing teacher learning opportunities for the maximum benefit of both teachers and students by establishing communities of learning. Similarly, Constantinou (2009) believes that reflection helps the EFL practitioner to update pedagogical practices which result in enhanced student performance. Zwozdiak-Myers (2011) adds that reflective practice's purpose is to raise educational standards and 'maximize the learning potential of all students with a focus on professional accountability through evidence-based outcomes (p.26).' In this respect, Shulman, (1987) stresses that what teachers teach is equally significant as how they teach, and the end of the result is the student learning. According to Jonassen (1999), the process of reflection, analysis and interpretation undertaken by teachers to improve their teaching practices imply the learning processes expected from students.

Based on Zeichner and Liston's (1996) description of the 5 dimensions of reflections, the behaviors which characterize these dimensions range from split-second real-time decision making to long-term reformulation of practical theories. The following sentences present the characterization of the behaviors:

\section{Rapid reflection happens very quickly; characterized as routine and automatic.}

2. Repair reflection, where the teacher makes decisions to alter his or her behavior in response to cues from students as evidence they don't understand. Those first two dimensions occur during reflection in action.

3. Reflection on action where the teacher reflects for future action. The third level concerning the review reflection is when a teacher thinks, discusses or writes about some element of his or her teaching or student learning. It can be as simple as an after class conversation with a colleague, or can consist of a more systematic approach, such as writing a students' progress report.

4. The fourth level concerns research, in which teachers' thinking and observation becomes more systematic and sharply focused around particular issues. It is a long-term process involving systematic in-depth teaching journal entries as data collection.

5. The last dimension, consisting of the re-theorization and the re-formulization of teaching practices (Zeichner and Liston,1996, p. 45-46 cited in Bailey, 2003).

Being effective at managing learners and their learning in the language classroom involves all the constituents of Freeman's model (1989): awareness, attitude, skills, and knowledge. The value of teacher's participation in reflective practice is to allow us to examine and to improve upon our own attitudes, skills, and knowledge and most importantly our awareness. There are more dimensions to reflective teaching and that is to engage effectively in the process requires the development of specific skills such as keen observation, logical reasoning, analysis, synthesis, and evaluation (Bloom, 1956), Reflection is an integral part of Kolb's (1984) model of experiential learning, in which immediate or concrete experiences provide the basis for observations and reflections. A reflective teacher observes and analyzes what he/she does from various perspectives and translates insights into active change and solves new problems through selfevaluation. Mak (2011) notes that reflective tools and activities could be designed to help student teachers to reflect on their past learning experiences to discuss their teaching decisions and articulate their thoughts behind their actions, through which student teachers could make more informed decisions in their teaching.

Bailey (1997) says that reflective teaching relies on a multi-dimensional approach of self inquiry which may orient teachers to be researchers as these personal experiences are shared in national and international teaching forums. It is a means to solve problems in a systematic manner during the professional journey of teaching. Also, a reflective practice leads to growth and development where eventually becomes a transformative journey (Black, 2013). Mathew (2012) notes that everyday classroom teaching-learning practices have to be considered as a rich kind of data for teachers to use as a basis for reflective practice on teaching and learning approaches. A reflective teacher is able to recognize the extent to which he or she has achieved the intended objectives of the teaching activities and such reflection allows for modifications in teaching approaches and curriculum construction.

There have been a number of past studies that reported the importance of reflective practice in the classroom as well as its challenges. Tugui (2011) and Racdulescu (2012) claim the importance of teaching teachers to be reflective at earlier stages of the professional development, so that individuals can be more receptive to change throughout their career. A systematic enquiry method was used then, and results show that this approach can deeply facilitate reflection, lead to autonomous learners who can merge their old and new beliefs/ theories and make right decisions for altering to professional practices. Due to reflective practices, individuals can be more receptive and productive throughout their careers, and this will help them to make the appropriate and right decisions for changing to professional practices. Furthermore, Sellars (2012) acknowledges the significance of the role of reflective practice in the teacher's life, development and change. They must exhibit the willingness to examine issues critically and analytically which requires authentic reflection. Mezirow (1990) argues that no update learning and re-examination of the new teaching theories and beliefs may lead to ineffective teaching. He further acknowledges the fundamental role of such learning revision in enhancing the quality of teaching, which in turn improves students' learning outcomes. Additionally, Mak (2011) signifies that a lack of reflection would slow down professional growth.

However, recently in Sudan, Yousif (2014) notes some problems within some undergraduate students, supposed to be teachers, who were found to apply various reflective processes in order to be aware of classroom practice. The 
framework consists of observation, experiential practice, personal evaluation, group discussion, and comments by mentors. The problems and solutions to such activities may require time to be implemented successfully. As (Hoover, 1994 as cited in Yousif, 2014) argues that professional development activities may require sufficient time to develop students' awareness and to equip them with different procedures of reflection that will support their practicum course as well as their profession.

\subsection{Reflection: a path towards teacher development}

There are many models which are applied in teacher education such as the craft model study, the applied Science model and the reflective model (Wallace, 2011). All three models have reached a level of professional competence. The following models are further described by Wallace (2011).

The Craft model is when a new teacher learns from an experienced mentor teacher through demonstration and instruction. The hypothesis concludes that with sufficient practice the beginner teacher will gain professional competence. However, this model lacks exposure to new and updated methods of teaching, which in turn may affect its validity and reliability. The Applied model is a model by which a new teacher learns from an expert theoretician. Theory is applied in the classroom, but it is also criticized since theory does not actually link with practical classroom experiences. However, the applied science model can offer guiding sets of principles against which one can plan and carry out pedagogic routines.

The Reflective model, on the other hand is based on two types of knowledge: received knowledge which relates to: 1. research-based facts that are passed on to use and, 2. experiential knowledge, which is the knowledge (often subconscious) that comes from experience. This is also described as knowing in action by Schon (1983), where trainees are encouraged to reflect through a variety of means including discussion groups, dairy writing and developing action plans.

Wallace (2011) notes reflective practice can provide a framework for practice in English language teaching within which professionals can work by comprehending of why certain techniques are used and how efficient they are to the students' learning experience. Thus, he adds that the reflective model has a motive of reaching professional competence and also improving the quality of reflection in professional education and development, To practice reflective teaching teachers are paving a journey to teacher development. These are exhibited in the process of teacher change and CPD Continuous Professional Development. Pennington (1992) stresses that teacher change and developments require an awareness of a need to change, and consider reflection as input output of development. She further proposes reflective developmental orientation 'as a means for (1) improving classroom processes and outcomes, and (2) developing confident, self-motivated teachers and learners' (Pennington 1992, p. 51). The focus here is on analysis, feedback, and adaptation as an ongoing recursive cycle in the classroom.

With reflective practice, teachers tend to develop changes in terms of enhanced professionalism and self-development. This is where teacher change comes in place. Richardson and Placier (2001) suggest that teacher change can be described in terms of learning, development, socialization, growth, improvement, implementation of something new or different, cognitive and affective change and self-study. Bailey (1992) emphasizes the six catalysts for teacher change which are: dissatisfaction with the current situation 2) the connection of a new idea with the teacher's own situation 3) a change in the teaching context 4) life changes and personal growth which led to professional development 5) a realization of something based on their experiences as a learner and 6) a conflict between the teacher/s new beliefs and their practice (p. 115).

With reflective practice the tendency to develop one's CPD is inevitable in order to establish a context for lifelong learning. Shulman (1987) highlights the development of one's teaching in the context of lifelong learning as well as reflecting strengths and also devising an action plan and set personal goals. With reflective teaching, the teacher is able to practice research, reflect on her findings and apply them in the classroom. Reflective teaching thus paves the way to teacher development as well as CPD where she is continuously enhancing her craft through reflection and making pertinent decisions relating to learning and teaching in the classroom. Teacher change also provides a transformation of skills and instruction to the better.

Bolam (2000) reasserts the significance of individual professional development for teachers in order to serve the purpose of CPD. CPD raises the standard of quality teaching for the purpose of educating the students successfully (Bolam, 1993).

CPD embraces those education, training and job-embedded support activities engaged in by teachers following their initial certification, and head teachers. Such activities are aimed primarily at adding in their professional knowledge, improving their professional skills and helping them to clarify their professional values so that they can educate their students more effectively (Bolam, 1993, as cited in Bolam, p. 267, 2000).

Gonzalez (2002) implies for self-actualization to take place for EFL teachers to reach their ultimate professionalism, professional development programs represent a way to fulfill their highest needs through reflection and creativity in their profession. They look for alternatives that promote group work and involve the community of teachers to achieve the goals proposed. 


\section{Methodology}

\subsection{The participants}

One hundred female teachers were selected randomly from three campuses and participated in the study. The participants were not only new teachers but also those who had experiences in teaching. They were of different levels of proficiency (BA, MA, and $\mathrm{PhD})$.

\subsection{The questionnaire}

A Likert Scale defined online questionnaire: (www.surveygizmo.com) was created, and it contained twenty nine closed questions and three open-ended questions that aim at gathering information on how teachers' perceive teacher development and their opinions towards reflective teaching. The closed questions section was divided into five parts: The first part included a question about teacher qualifications. Part two included items about the definition of teacher development. Part three presented items which dealt with teacher development activities. Part four comprised items about the relationship between reflective teaching and teacher development. Finally, part 5 which encompassed openended questions about the usefulness of teacher development activities.

\subsection{Data Procedure}

The data is analyzed using descriptive statistics specifically frequency and percentile scores. A preliminary questionnaire was piloted by (10 teachers) due to availability. Wilkinson and Birmingham (2003) point out that it is crucial to design the questions carefully to meet the research objectives, and to test them prior to conducting research. The questions were revised based on specific items in the questionnaire. Some questions were ambiguous and redundant, and thus there were deleted from the questionnaire. Once the data was collected statistical descriptive (totals, and percentages) were generated through the online questionnaire. The data for the open-ended questions were revised manually for common themes.

\section{Results and Discussion}

\subsection{Teachers' views towards Teacher Development}

As mentioned previously, the first research question concerns Saudi teachers' knowledge about Teacher Development. To investigate this issue, 5 Likert-point scale and open ended question types were used. To begin with, the following figure reflects teachers' degree of agreement towards the concept of Teachers Development. As it is displayed, most teachers agreed and strongly agreed with the statements 1,2 and 3 concerning the relationship between teachers' development, professionalism and teaching improvement. The majority of teachers admitted the crucial role of teaching development in enhancing teaching and attaining professionalism. They contended that such process change them into skilled and creative teachers.

Such results correlated with the participants' responses to the open ended questions related to the same item. They stressed the fact that teaching development is an ongoing improvement process through which teachers keep learning from previous experiences and attending workshops in order to keep updated to new teaching methods and to be competent and professional in teaching. Furthermore, in emphasizing the idea of becoming creative, other teachers said that "Development is a kind of transformation from the old to the new, from the known to the unknown, from the familiar to the unfamiliar"

These findings are consistent with those of Al-Issa (2005) who found that the teachers agreed on the usefulness of the pedagogical training courses and the specialization courses in constructing a sense of creativity and development in their teaching practices. Meanwhile, teachers agreed and strongly agreed with the factors leading to teaching development. Most teachers perceived that feedback from peers, mentors and students plays a crucial role in enhancing teachers' development. Similarly such findings correlated with the participants responses to the open ended question. They acknowledged that "Mentoring and feedback from colleagues are critical to the successful development of new teachers. Great induction programs create opportunities for novice teachers to learn from best practices and how to reflect on their own teaching".

Such results concerning the relationship between teachers' cooperation and teachers' development seemed to reaffirm the suggested point of view of Stenhouse (1975) who stresses teachers' reflection and development through engaging oneself in teaching observation.

Besides, referring to items 9 and 10, about 50\% of teachers agreed and strongly agreed with the statement that 'Teachers' development can occur through teachers observation which in turn enhance their reflection on teaching" pointing out that it is an opportunity for self-analysis in teaching. Through reflection, teachers become empowered and gain an awareness of their teaching competence and performance.

However, concerning item 3, the majority of teachers disagreed and strongly disagreed with the statement arguing that teachers' development is the same as teachers' education. They viewed that a teacher after accomplishing his/ her education should progress and improve his/her teaching methods, by being updated to the new research studies and the advocated approaches and by attending conferences. In this respect, when analyzing the open ended questions, the participants stressed the fact that attending workshops, conferences and seminars after finishing one' education enhances teachers' teaching skills and keep them updated of the best practices in language learning and teaching pedagogy. For further description of all the explained items, please refer to the following figure 4.1 


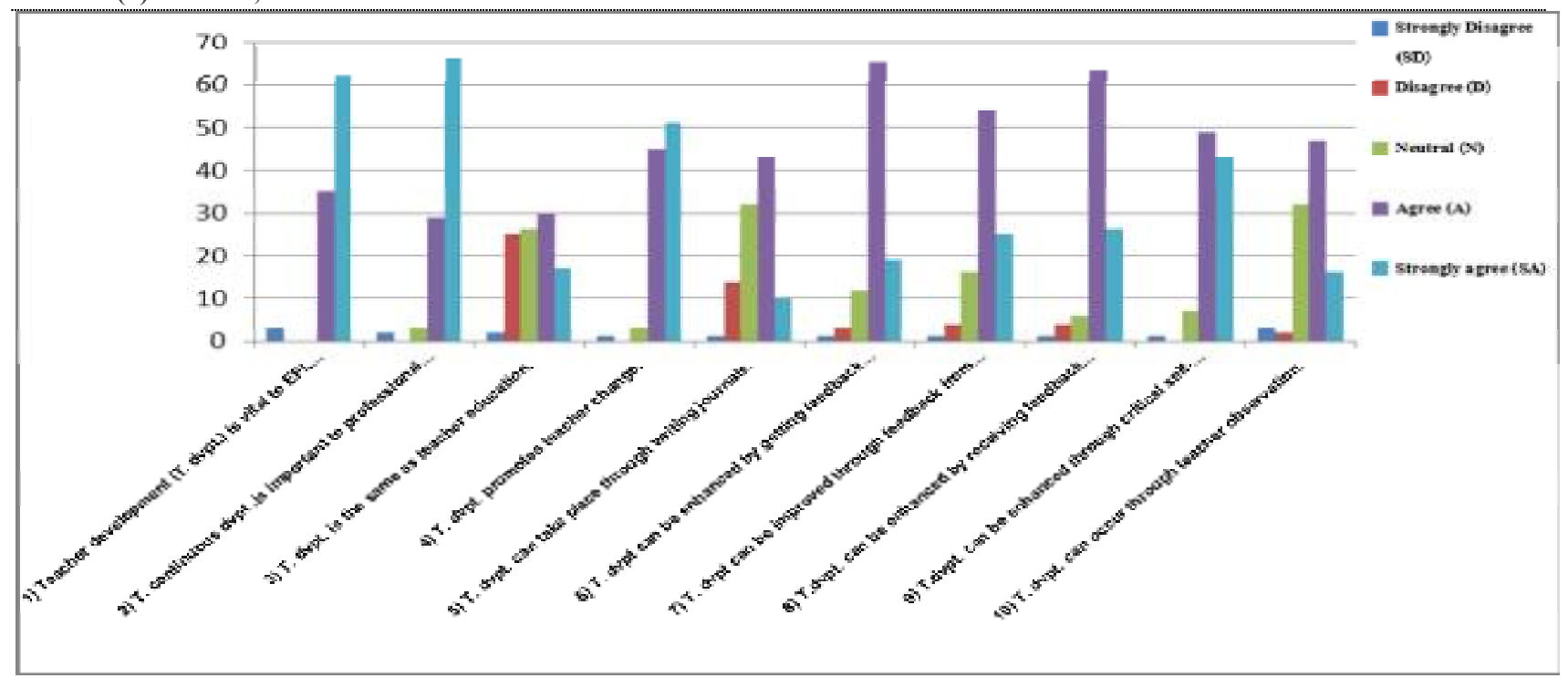

Figure 4.1 Teachers' knowledge about teachers' development.

\subsection{Activities related to teachers' development}

The following figure displays the different activities that teachers practice to enhance their teaching.

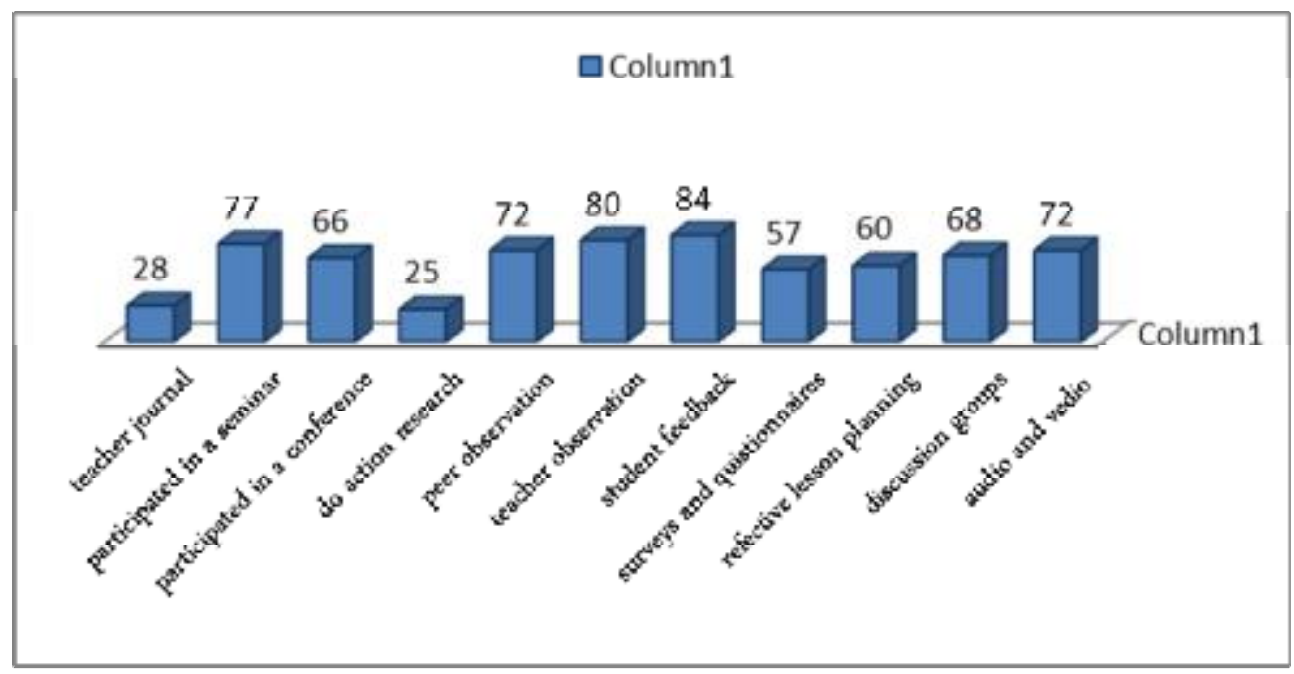

Figure 4.2 Teachers' development activities

As represented in figure 4.2 teachers used a variety of activities in an attempt to enrich their teaching practice. To illustrate, about $84 \%$ of teachers got involved in teachers' observations and peer observations and got feedbacks to improve their quality of teaching as well as their approaches. Moreover, $77 \%$ of the participants attended conferences and participated in conferences in attempt to keep updated to the new methods of teaching and be creative and professional in their work. Other activities are also mentioned such as doing researches, administrating questionnaires, doing reflective lessons, and sharing feedback with students. These activities are recognized as useful and helpful. The participants admitted that whatever the activity they select their effort to think about a problem in their teaching approach and how to solve that using appropriate and motivated techniques helps to improve and enhance their teaching skills. These findings also support the different tasks suggested by Gonzalez (2002) and Pollard (2005) who put an emphasis on teachers' engagement in such activities in order to achieve growth development and reach professionalism in their teaching practices.

\subsection{Relationship between teachers' development and reflective teaching}

In investigating the relationship between teachers' development and reflective teaching, it is important to examine the concept of reflective teaching and how Saudi teachers perceive it. As the following figure 3.3 shows, 17 items of 5 point Likert scale were designed to figure out the participants' views towards reflecting teaching. The results were significant in that almost all teachers agreed and strongly agreed with the seventeen items which emphasize the importance of reflective teaching taking into consideration its relation to teaching development, critical thinking and continuous professionalism. As an illustration, $90 \%$ of the participants agreed and strongly agreed with the statement denoting that reflective teaching promotes future action, teacher growth and empowerment. Such findings confirm the claim made by Bolam (2000) who acknowledges the fundamental role of the Reflective teaching in strengthening teacher development as well as CPD. Instantaneously, Tugui (2011); Racdulescu (2012) and Sellars (2012) share similar views. 
Such finding is also correlated with the participants' responses in the open ended question. They asserted that reflective teaching is a tool to develop professionally as it helps them to critically analyze and evaluate the existing teaching practices. Such a reflection in teaching is an opportunity of an ongoing self-assessment of one's competence in teaching, classroom management, the use of the appropriate pedagogical approaches and the effective employment of teaching techniques. To this point, the participants clearly stated that reflective teaching is basically self-observation and self evaluation. It is a deeper understanding of the teacher's own teaching style that enhances his/her effectiveness in the classroom milieu. Through this way, they can identify and explore their teaching practices which may further lead to improved teaching strategies and hence attaining professional development. For further description of the participants' agreement towards reflective teaching items, please refer to figure 4.3 below.

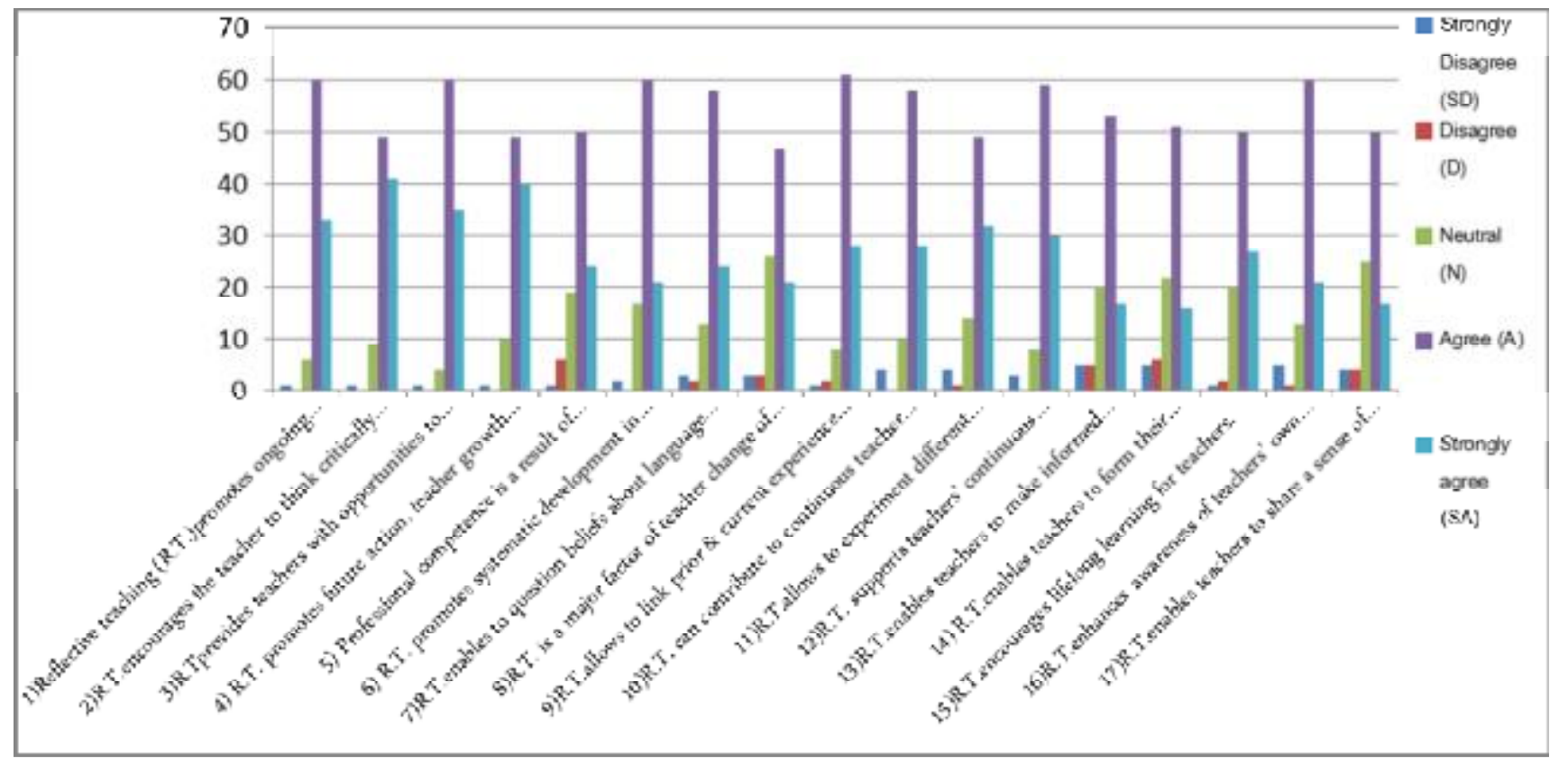

Figure 4.3 Agreement items towards reflective teaching

\section{Conclusions and further research}

The present study investigated the relationship between teacher development and reflective teaching. The study obtained similar results as those of previous research studies mentioned in the literature review section. The results of the present study suggested the critical role of the reflective teaching practices in enhancing teaching development and achieving creativity. To this point, Pollard (2005), Zwozdiak-Myers, (2011) and Black (2013) highlight the importance of reflective practice is to assist teachers to become better educators and raise educational standards. Consequently, our institutional organizations should take into considerations to provide ways to help teachers become reflective through the following suggested points:

- More training through collaborative venture of reflective practice between experienced and novice teachers such as peer tutoring (Harmer, 2007).

- Mentorship schemes to support novice teachers and experienced teachers.

- Support from administrators for teachers to network and produce profound results professionally. Teachers may need to move from individual awareness to groups of schools working together doing research, and consequently solve problems together (Gonzalez, 2002, Desimons, 2009).

- Research in classroom teaching and learning for the purpose of becoming reflective practitioners.

A further important result concerned the participants' agreement towards the idea that the teaching development is an ongoing improvement process. They strongly agreed that teachers have to keep learning from previous experiences, attending workshops and doing empirical research studies in classroom in order to keep updated to the new teaching approaches, try to find solutions and attain professionalism in teaching. Although the present study obtained crucial findings, it had some shortcomings presented in its methodology such the use of a one-type research instrument. Therefore, the employment of varied instruments such class observations, role plays and interviews will have a more comprehensive and clear image about teachers' use of the reflective activities in achieving better teaching outcomes. Nevertheless, the present study has a number of pedagogical implications. One of the most obvious is the importance of teachers' training, which requires institutional and governmental assistance in providing professional trainers, providing diverse teaching materials with help of technology and offering scholarships for carrying out more research. That might, in turn, facilitate teachers' mission in doing investigation for the sake of developing their teaching competences as well as empowering students' learning outcomes. 


\section{References}

Al-Issa, A.and Al-Bulushi, A. (2010). Training English Language Student Teachers to Become Reflective Teachers. Australian Journal of Teacher Education, 35, 4, 41-64.

Al-Issa, A. (2005). The Implications of the teacher educatior's role in the ELT system in Oman.Teaching Education, 16, 4, 337-348.

Al-Shihy, H. (2003). Omani English teachers' perceptions of the teacher education program Sultan Qaboos University: an evaluative study. Unpublished Masters dissertation. Sultan Qaboos University, Oman.

Bailey, K. M. (1992). The use of diary studies in teacher education programmes. In Richards, J. C. Richards and D. Nunan. (eds.) Second Language Teacher Education (pp.215-226). Cambridge: Cambridge University Press.

Bailey, K. M. (1997). The processes of innovation in language teacher development: what, why and how teachers change. In J. Flowerdrew, M. Brook \& S. Hsia (eds.) Teacher Education (253-282). Hong Kong: City Polytechnic of HK.

Bailey, K. (2003). Plenary: Language teaching journals and reflective teaching. Alza Pulverness, (ed.). IATEFL 2003, Brighton Conference Selections.

Bartlett, L. (1990). Teacher Development Through Reflective Teaching. In J.C. Richards and D. Nunan, Second Language Teacher Education (pp.202-214). New York: Cambridge University Press.

Black, M. (2013). Reflective Teaching Practices: Looking Beneath the Surface and Emergent

Cyclical Experiential Learning Processes. (Master of Arts, MA TESOL Collection, Graduate Institute, Vermont).

Retrieved from http://digitalcollections.sit.edu/ipp_collection/696/

Bloom, H. (1956). Taxonomy of Educational Objectives, Handbook 1: Cognitive Domain. London: Longman.

Bolam, R. (1993). Recent Developments and Emerging Issues,in GTC Trust (ed.) The Continuing Professional Development of Teachers, London: GTC Trust.

Bolam, R. (2000). Emerging Policy Trends: some implications for continuing professional development. Journal of InService Education, 26, 2, 267-280.

Borg, S. (2003). Teacher cognition in language teaching: a review of research on what language teachers think, know, believe, and do. Language Teaching, 36, 2, 81-109.

Borg, S. (2006). Teacher Cognition and Language Education. Norfolk: Biddles Ltd.

Constantinou, H. (2009). Reflection in Education: An Exploration of EFL Teachers' Conceptions of Reflective Practice in the UAE. Thesis submitted for the degree of Doctor in Education. http://hdl.handle.net/10036/80502

Desimons, M. L. (2009). Improving Impact Studies of Teachers' Professional Development: Toward Better Conceptualizations and Measures. Educational Researcher Journal, 38, 3, ProQuest Central, 181-198.

Dewey, J. (1933). How we Think: A Restatement of the Relation of Reflective Thinking to the Educative Process. Boston, MA: DC Health and Company.

Freeman, D. (1982). Observing teachers: three approaches to in-service training and development. TESOL Quarterly, $16,1,21-8$.

Freeman, D. (1989). Teacher Training, Development and Decision Making: A Modelof Teaching and Related Strategies for Language Teacher Education, TESOL QUARTERLY, 23, 1,27-45.

Gonzalez, M. A. (2002). What do EFL Teachers seek in Professional Development Programs? Voices from Teachers. IKala, revista de lenguaje y cultura journal, 17, 13, 29-50.

Hazmi, S. (2003). EFL Teacher Preparation Programs in Saudi Arabia: Trends and Challenges.TESOL QUARTERLY, $37,2,341-344$.

Head, K. and Taylor, P. (1997). Readings in Teacher Development. Oxford, United Kingdom: Macmillan Publishers Limited.

Hoover, L. (1994) Reflective writing in a window on pre-service teachers thought processes, Teaching and Teacher Education, 10, 83-93.

Jonassen, D. (1999). Designing constructivist learning environments. In C. M. Reigeluth (Ed), Instructional Theories and Models (2nd ed. pp. 215-239). Mahwah, NJ: Lawrence Erlbaum Associates.

Kolb, D. (1984) Experiential Learning at the Science of Learning and Development. Englewoods Cliffs, NJ: Prentice Halls.

Mak, H. S. (2011). Tensions Between Conflicting Beliefs of an EFL Teacher in Teaching Practice. RELC Journal, 42, 1, 53-67. doi:10.1177/0033688210390266. http://rel.sagepub.com/content/42/1/53.

Mathews, N. (2012). Reflective Classroom Practice for Effective Classroom Instruction. International Education Studies, 5, 3, 205-211.

Mezirow, J. (1990). Fostering Critical Reflection in Adulthood. Mezirow and Associates: Jossey Bass. 
Pennington, M. (1992). Reflecting on Teaching and Learning. A development focus for the second language classroom. Kowloon: City Polytechnic of Hong Kong.

Pollard, A. (2005). Reflective Teaching. ( $2^{\text {nd }}$ ed.). London: Continuum.

Racdulescu, C. (2012). Reinventing Reflective Learning Methods in Teacher Education. Procedia Sociol and Behavioral Sciences. 78, 11-15.

Richardson, V., \& Placer, P. (2001). Teacher change. In V. Richardson (Ed.), Handbook of research on teaching (4th ed, pp. 905-947).Washington, DC: American Educational Research Association.

Richardson, V. (1996). The role of attitudes and beliefs in learning to teach. In J. Sikuala, T. J. Buttery \& E. Guyton. (Eds.), Handbook of Research in Teacher Education (pp.102-119). New York: Macmillan.

Schon, D. (1987). Educating the Reflective Practitioner. San Francisco, CA: Jossey-Bass.

Sellars, M. (2012). Teachers and change: The role of reflective practice. Procedia-Social and Behavioral Sciences. 55, 461-469.

Shulman, L. (1987). Knowledge and teaching foundations of the new reform, Harvard Educational Review, 57,1,2-21.

Stenhouse, L. (1975). An introduction to Curriculum Research and Development. London: Heinemann Education.

Thornbury, S. (2006). An A-Z of ELT. Oxford: Macmillan Publishers.

Tugui, C. (2011). Systematic reflective enquiry methods in teacher education, Procedia Sociol and Behavioral Sciences, 29, 533-538.

Underhill, A. (1988). Training development and teacher education. In Teacher Development Newsletter, 9, p. 4.

Wallace, J. M. (2001). Training Foreign Language Teachers: A reflective approach. Cambridge: Cambridge University Press.

Wilkinson, D. and Birmingham, P. (2003). Using Research Instruments: A Guide for Researchers. London: Routledge Falmer.

Woodward, T. (1991). Models and Metaphors in Language Teacher Training: Cambridge: Cambridge University Press. Yousif, A. A. (2014). Collaborative Reflection: Vehicle for Professional Growth. Arab World English Journal, 5,1, 8998.

Zeichner, K. M. and D. P. Liston. (1996). Reflective teaching: An introduction. Mahwah. NJ: Lawrence Erlbaum Associates Publishers.

Zwozdiak-Myers, Paula (2011). Reflective practice for professional development. In A.Green. Becoming a Reflective Teacher (pp.26-42). England: Open University Press. 